\title{
EFEKTIVITAS KONSENTRASI GIBERELIN DAN KONSENTRASI PUPUK HAYATI TERHADAP PRODUKTIVITAS OKRA (Abelmoschus esculentus)
}

\author{
The Effectiveness of Giberellin Concentration and Biological Fertilizer \\ Concentration on Productivity of Okra (Abelmoschus esculentus)
}

\author{
Muhammad Chabib Ichsan, Iskandar Umarie, dan Guruh Fani Sumantri \\ Prodi Agroteknologi, Fakultas Pertanian Universitas Muhammadiyah Jember \\ e-mail : ${ }^{1}$ chabib@unmuhjember.ac.id, ${ }^{2}$ iskandarumarie@unmuhjember.ac.id, \\ 33uruhfani1996@gmail.com
}

\begin{abstract}
ABSTRAK
Penelitian ini bertujuan untuk mengetahui efektifitas pemberian konsentrasi fitohormon Giberelin GA3 dan konsentrasi pupuk hayati dan juga kombinasi kedua variabel tersebut terhadap produksi okra (Abelmoschus esculentus). Penelitian ini dilaksanakan di Pedukuhan Plendu, Kelurahan Karangrejo, Kecamatan Sumbersari, Kabupaten Jember. Dimulai tanggal 22 November 2017 sampai tanggal 12 Maret 2018. Dengan ketinggian \pm 89 meter di atas pemukaan laut (mdpl). Penelitian dilakukan secara faktorial dengan pola dasar Rancangan Acak Kelompok (RAK) faktorial terdiri dari dua faktor yaitu faktor pertama konsentrasi pemberian Giberellin GA3 yaitu : tanpa perlakuan giberelin GA3, Giberellin GA3 125 ppm, Giberellin GA3 250 ppm, dan Giberellin GA3 375 ppm. Faktor kedua konsentrasi pemberian pupuk hayati yaitu: tanpa perlakuan pupuk hayati K-Bioboost, pupuk hayati 40ml/l, pupuk hayati $80 \mathrm{ml} / \mathrm{l}$, dan pupuk hayati $120 \mathrm{ml} / \mathrm{l}$, setiap perlakuan diulang sebanyak $3 \mathrm{kali}$. Hasil penelitian menunjukkan bahwa efektifitas interaksi antara Giberellin GA3 pada konsentrasi $375 \mathrm{ppm}$ dan pupuk hayati K-Bioboost pada konsentrasi $40 \mathrm{ml} / \mathrm{l}$ air terhadap produksi okra menghasilkan jumlah buah sebesar 33 buah per tanaman dengan peningkatan efektifitas sebesar $51 \%$ dan sebanyak 836 buah per petak dengan peningkatan efektifitas sebesar $48 \%$. Berat buah diperoleh produksi seberat 5,21 gram per tanaman dengan peningkatan efektifitas sebesar $17 \%$ dan seberat 7343 gram per petak dengan peningktan efektifitas sebesar $45 \%$, dengan konversi berat buah okra sebesar 22,25 ton per hektar.
\end{abstract}

Kata Kunci : Tanaman Okra, Giberellin GA3 dan pupuk hayati.

\begin{abstract}
The aim of this study is to determine the effectiveness of the concentration of phytohormone Giberelin, Biofertilizer and also the combination of these two variables on the production of okra (Abelmoschus esculentus). This research was carried out on located at Plendu Street, Sumbersari District, Jember Regency. Starting on November 22, 2017 until March 12, 2018. With an altitude of +89 meters above sea level (masl). The research was carried out factorially with the factorial basic pattern of randomized block design consisting of two factors: the first factor was the concentration of Giberellin GA3 administration, namely: without treatment of giberelin GA3, giberellin GA3 125 ppm, giberellin GA3 250 ppm, and
\end{abstract}


giberellin GA3 375 ppm. The second factor concentration of the provision of natural fertilizer, amount : without treatment of natural fertilizer, natural fertilizer 40ml/l of woter, natural fertilizer $80 \mathrm{ml} / \mathrm{l}$ of woter, and natural fertilizer $120 \mathrm{ml} / \mathrm{l}$ of woter. Each treatment was repeated 3 times. The results showed that the effectiveness of the interaction between Giberellin GA3 at a concentration of 375 ppm and K-Bioboost natural fertilizer at a concentration of $40 \mathrm{ml} / \mathrm{l}$ of water to the production of okra produced a fruit amount of 33 per plant with an increase in effectiveness of $51 \%$ and as many as 836 pieces per plot with increased effectiveness by 48\%. The weight of fruit was 5.21 grams per plant with an increase in effectiveness of $17 \%$ and weighing 7343 grams per plot with an increase in effectiveness of $45 \%$, with the conversion of okra fruit weight of 22.25 tons per hectare.

Keywords: Okra plant; Giberellin GA3 and natural fertilizer

\section{PENDAHULUAN}

Okra disebut Abelmoschus turbulantus, Hibiscus esculentus, dan Hibiscus longifolius pada beberapa literatur. Abelmoschus adalah tanaman asli Asia Tenggara, termasuk Abelmoschus esculentus. Okra merupakan tanaman dalam family Mallow (malvaceae) yang sangat mirip dengan kapas (Gossypium hirsutuml/l.) tetapi buah dan daunnya lebih panjang dan dilindungi bulu serta lilin, sehingga sering disilangkan untuk mendapatkan tanaman kapas yang tahan serangan ulat. Umumnya okra di panen dalam bentuk polong muda dan digunakan sebagai sayuran, baik tersendiri maupun dicampur dengan sayuran lain (Yudo, 1991).

Okra dapat tumbuh di dataran rendah sampai dataran tinggi pada hampir semua jenis tanah dengan $\mathrm{pH}$ tanah minimal 4,5, syarat tumbuh yang diutamakan adalah pada suhu netral dengan $\mathrm{pH}$ antara 6,5 - 7,5. Okra dapat tumbuh dengan baik pada tanah berpasir dengan pengairan yang baik. Sedangkan suhu optimal untuknya adalah $28-30^{\circ} \mathrm{C}$ (Singh, 2008).

Okra atau bendi memiliki berbagai manfaat untuk kesehatan, di luar beberapa jenis vitamin dan protein yang terdapat di dalamnya. Okra merupakan sayuran hijau berserat yang mengandung vitamin, mineral, folat, dan anti-oksidan seperti beta karoten dan lutein (Asalm, et al, 2010). Okra juga rendah kalori sehingga dapat dijadikan menu dalam diet menurunkan berat badan. Manfaat okra bagi kesehatan manusia antaralain mencegah diabet, karena bisa menurunkan kadar gula darah dan kolesterol, menyehatkan pencernaan, menjaga kesehatan dan mempercantik kulit, mencegah kerontokan rambut, menurunkan berat badan, baik untuk jantung, melawan penyakit ginjal, sumber serat larut, mengatasi anemia, mengatasi radang tenggorokan dan batuk, serta mengatasi diare dan sembelit (Ansari dan Sukhraj, 2010).

Produksi okra saat ini masih cenderung fluktuatif, dan belum mampu memenuhi kebutuhan sayuran okra nasional. Produksi okra pada tahun 2013 sebesar 1.317 ton dan pada tahun 2014 sebesar 1.360 ton, sedangkan kebutuhan okra pada tahun 2015 diproyeksikan mencapai 1.500 ton (Suntoro, et al, 2014). Salah satu cara untuk meningkatkan produksi okra

yaitu melalui pemupukan. Pemupukan bertujuan mengganti unsur hara yang hilang dan menambah persediaan unsur hara yang dibutuhkan tanaman untuk meningkatkan produksi dan mutu tanaman.Ketersediaan unsur hara yang lengkap dan berimbang yang dapat diserap 
oleh tanaman merupakan faktor yang menentukan pertumbuhan dan produksi tanaman Okra (Nyanjang, 2003).

Kemajuan teknologi dalam bidarg pertanian sebagai dampak dari revolusi industri, revolusi kimia, dan revolusi hijau, mampu meningkatkan pertumbuhan ekonomi secara global, betapa pun juga membawa dampak negatif. Ton (1991) mengatakan bahwa di negara-negara dunia ketiga yang sedang berkembang yang mencukup kebutuhannya sendiri dalam bidang pangan/sandang, penggunaan bahan-bahan kimia pertanian membantu pada kemajuan dan perkembangan pertanian selanjutnya. Tetapi di negara-negara berkembang telah mengurangi penggunaan dari bahan-bahan kimia pertanian karena merupakan salah satu penyebab utama dari pencemaran lingkungan. Pencemaran lingkungan terutama lingkungan pertanian disebabkan oleh penggunaan bahan-bahan kimia pertanian. Telah dapat dibuktikan secara nyata bahwa bahan-bahan kimia pertanian dalam hal ini pestisida, meningkatkan produksi pertanian dan membuat pertanian lebih efisien dan ekonomi.

Sejalan dengan kemajuan teknologi, kini ditemukan jenis pupuk baru yaitu pupuk hayati, yang isinya berupa mikroba penyubur tanah.Kandungan mikroba mampu membuat pupuk ini ramah lingkungan. Mikroba tersebut bermanfaat dalam proses biokimia di dalam tanah sehingga unsur hara menjadi lebih mudah diserap akar tanaman, akibatnya tanaman akan tumbuh lebih optimal. Pupuk hayati ini mengadung bakteri-bakteri yang berguna untuk memacu pertumbuhan tanaman sehingga hasil produksi tanaman tetap tinggi dan berkelanjutan. Hartatik (2006) menyatakan bahwa selain sebagai sumber hara dan sumber energi bagi aktivitas mikroba dalam tanah, pupuk organik memiliki kelebihan, yaitu dapat memperbaiki kesuburan fisik, kimia dan biologi tanah. Pupuk hayati merupakan mikrobia yang diberikan ke dalam tanah untuk meningkatkan pengambilan hara oleh tanaman dari dalam tanah atau udara. Mikrobia yang digunakan umumnya mikrobia yang mampu hidup bersama (simbiosis) dengan tanaman inang. Keuntungan dimana diperoleh oleh kedua pihak, tanaman inang mendapatkan tambahan unsur hara yang diperlukan. Mikrobia yang terkandung dalam pupuk hayati antara lain mikrobia penambat $\mathrm{N}$, mikrobia dekomposisi bahan organik, mikrobia dekomposisi residu pestisida dan mikrobia untuk meningkatkan ketersedian P dalam tanah (Suroso, 2015).

Walaupun saat ini telah diketahui tumbuhan dapat menghasilkan GA3 sendiri, akan tetapi jumlah yang dihasilkan sendiri oleh tumbuhan tersebut belum cukup untuk merangsang pertumbuhan. Giberelin merupakan zat pengatur tumbuh yang berperan merangsang perpanjangan ruas batang, terlibat dalam inisiasi pertumbuhan buah setelah penyerbukan (terlebih jika auksin tidak berperan optimal), giberelin juga meningkatkan besaran daun beberapa jenis tumbuhan. Respons terhadap giberelin meliputi peningkatan pembelahan sel dan pembesaran sel. Pupuk hayati merupakan mikrobia yang diberikan ke dalam tanah untuk meningkatkan pengambilan hara oleh tanaman dari dalam tanah atau udara. Mikrobia yang digunakan umumnya mikrobia yang mampu hidup bersama (simbiosis) dengan tanaman inang. Keuntungan dimana diperoleh oleh kedua pihak, tanaman inang mendapatkan tambahan unsur hara yang diperlukan. Giberelin dapat mempengaruhi antara lain panjang batang atau ruas batang, mendorong pembungaan, buah, tumbuhnya mata tunas yang dorman (Santoso dan Fatimah, 2004). 
Giberellin merupakan kelompok fitohormon yang terkait dengan dormansi dan perontokan daun (senescnese). Fitohormon Giberellin GA3 merupakan hormon yang mempercepat perkecambahan biji, kuncup tunas, pemanjangan batang, pertumbuhan daun, merangsang pembungaan, perkembangan buah, mempengaruhi pertumbuhan dan diferensiasi akar (Campbell, 2005). Giberellin bukan hanya memacu pemanjangan batang saja, tapi juga pertumbuhan seluruh tumbuhan, termasuk daun dan akar. Bila giberellin diberikan di tempat yang dapat mengangkut ke apek tajuk, peningkatan pembelahan sel dan pertumbuhan sel tampak mengarah kepada pemanjangan batang dan (pada beberapa spesies) perkembangan daunya berlangsung lebih cepat, sehingga memacu laju fotosintesis yang berdampak kepada menghasilkan peningkatan keseleruhan pertumbuhan, termasuk pertumbuhan akar, beberapa proses fisiologis yang di pengaruhi oleh giberellin adalah merangsang pemanjangan batang dengan pembelahan dang pemanjangan sel, merangsang pembungaan, memecah dormansi pada beberapa tanaman yang menghendaki cahaya untuk merangsang perkecambahan, perangsang produksi enzim (amilase) dalam mengecambahkan tanaman sereal untuk mobilisasi cadangan benih, menyebabkan berkurangnya bunga jantan pada bunga (dicious sex expression), dapat menyebabkan perkembangan buah partenokapri (tanpa biji) serta dapat menunda penuaan pada daun dan buah jeruk (Salisbury dan Ross, 1995)

\section{METODE PENELITIAN}

Pelaksanaan penelitian yang berjudul "Efektivitas Konsentrasi Giberellin dan Konsentrasi Pupuk Hayati tTerhadap Produksi Okra (Abelmoschus esculentus L. Moench)“ yang dilaksanakan pada tanggal 22 November 2017 sampai dengan tanggal 12 Maret 2018 dilaksanakan di Pedukuhan Prindu, Kelurahan Karangrejo, Kecamatan Sumbersari, Kabupaten Jember. Bahan-bahan yang digunakan dalam penelitian ini adalah : benih okra (Abelmoschus esculentus L.), Giberellin GA3, dan Pupuk Hayati.

Alat-alat yang digunakan dalam penelitian ini adalah: handtractor, sprayer punggung semi otomatis, timba, cangkul, gembor, jangka sorong, neraca digital, gelas ukur, cetok, corong, jurigen, gayung, tali rafia, tugal, gunting, dan pemotong rumput.

Penelitian dilakukan secara faktorial dengan pola dasar Rancangan Acak Kelompok (RAK) Faktorial dengan faktor konsentrasi Fitohormon Giberellin GA3 dan Pupuk Hayati. Penelitian ini terdiri dari 2 (dua) factor perlakuan yang diulang 3 (tiga) kali.

Faktor Pertama : Konsentrasi Fitohormon Giberellin , terdiri dari :

$$
\begin{aligned}
& \text { * } \mathrm{G}_{0} \text { : Konsentrasi Giberellin }=0 \text { ppm. } \\
& \text { \# } \mathrm{G}_{1} \text { : Konsentrasi Giberellin }=125 \mathrm{ppm} \text {. } \\
& \text { * } \mathrm{G}_{2} \text { : Konsentrasi Giberellin }=250 \mathrm{ppm} \text {. } \\
& \text { * } \mathrm{G}_{3} \text { : Konsentrasi Giberellin }=375 \text { ppm. }
\end{aligned}
$$

Faktor Kedua : Konsentrasi Pupuk Hayati, terdiri dari :

$$
\begin{aligned}
& \text { \# } \mathrm{H}_{0}: \text { Pupuk Hayati }=0 \mathrm{ml} / \mathrm{l} / 1 \text { air. } \\
& \text { \# } \mathrm{H}_{1}: \text { Pupuk Hayati }=40 \mathrm{ml} / \mathrm{l} / 1 \text { air. } \\
& \text { \# } \mathrm{H}_{2}: \text { Pupuk Hayati }=80 \mathrm{ml} / \mathrm{l} / 1 \text { air. } \\
& \text { \# } \mathrm{H}_{3}: \text { Pupuk Hayati }=120 \mathrm{ml} / \mathrm{l} / 1 \text { air. }
\end{aligned}
$$


Dalam pelaksanaan dan perawatan penelitian yang perlu dilakukan mulai dari Penyiapan Benih, Pengolahan Lahan Tanah, Analisis Tanah, pemberian Pupuk Dasar, Pembuatan Bedengan (Plot), Penanaman dan Penyulaman, Penyiangan, Aplikasi Pupuk Hayati, Aplikasi Pemberian Giberellin GA3, Pengairan dan Penyiraman, serta Drainase dan Pengendalian Hama.

Variable pengamatan meliputi jumlah buah per tanaman, jumlah buah per petak, berat buah per tanaman, berat buah per petak, panjang buah per tanaman, dan berat brangkasan kering.

\section{HASIL DAN PEMBAHASAN}

\section{Hasil dan Komponen Hasil}

Hasil penelitian tentang efektifitas konsentrasi Giberellin GA3 dan Pupuk Hayati terhadap produktifitas okra (Abelmoschus esculentus) dengan jumlah buah per tanaman, jumlah buah per petak, berat buah per tanaman, berat buah per petak, panjang buah, berat brangkasan kering, sebagai variable pengamatan. Hasil pengamatan dianalisis menggunakan anilisis ragam dan jika terdapat pengaruh yang nyata atau sangat nyata maka akan dilanjutkan dengan uji Duncan. Adapun rangkuman hasil analisis ragam terhadap masing-masing variabel pengamatan disajikan pada Tabel 1.

Tabel 1. Hasil rangkuman analisis ragam terhadap semua variabel

\begin{tabular}{lccc}
\hline \multirow{2}{*}{ Variabel Pengamatan } & \multicolumn{3}{c}{ F-Hitung } \\
\cline { 2 - 4 } & $\begin{array}{c}\text { Gibrellin GA3 } \\
(\mathrm{G})\end{array}$ & $\begin{array}{c}\text { Pupuk Hayati } \\
(\mathrm{H})\end{array}$ & $\begin{array}{c}\text { Interaksi } \\
(\mathrm{G} \mathrm{x} \mathrm{H})\end{array}$ \\
\hline Jumlah Buah Per Tanaman & $185,51 * *$ & $25,46 * *$ & $12,91 * *$ \\
Jumlah Buah Per Petak & $320,87 * *$ & $23,86 * *$ & $8,94 * *$ \\
Berat Buah & $28,48 * *$ & $10,84 * *$ & $3,74 * *$ \\
Berat Buah Per Petak & $337,08 * *$ & $19,44 * *$ & $10,06 * *$ \\
Panjang Buah & $9,81 * *$ & $10,02 * *$ & $2,12 \mathrm{~ns}$ \\
\hline
\end{tabular}

Keterangan: $\mathrm{ns}=$ berpengaruh tidak nyata, $*=$ berpengaruh nyata, $* *=$ berpengaruh sangat nyata

Tabel 1 menunjukkan bahwa perlakuan pemberian Giberellin berpengaruh nyata pada jumlah buah per tanaman, jumlah buah per petak, berat buah per tanaman, berat buah per petak, panjang buah, dan berberda tidak nyata pada berat berangkasan kering. Pada perlakuan pemberian Pupuk Hayati sangat berpengaruh nyata pada jumlah buah per tanaman, jumlah buah per petak, berat buah per tanaman, berat buah per petak, panjang buah, dan berpengaruh tidak nyata pada berat berangkasan kering. Sedangkan pada interaksi kedua perlakuan menunjukkan sangat berpengaruh nyata jumlah buah per petak, berat buah per tanaman, berat buah per petak, dan berpengaruh tidak nyata pada panjang buah per tanaman, dan berangkasan berat kering. Adapun penjelasan terhadap masing-masing variabel pengamatan disajikan di bawah ini.

\section{Jumlah Buah Per Tanaman}


Hasil analisis ragam terhadap jumlah buah per tanaman menunjukkan bahwa perlakuan pemberian Giberellin GA3, pemberian Pupuk Hayati dan interaksi kedua faktor tersebut sama-sama menunjukkan berpengaruh sangat nyata dengan dilanjutkan analisis uji beda jarak berganda Duncan.

Tabel 2. Jumlah buah per tanaman yang dipengaruhi faktor pemberian Giberellin GA3 pada berbagai konsentrasi

\begin{tabular}{lcc}
\hline Pemberian Giberellin GA3 & Jumlah Buah Per Tanaman & \\
\hline G0 (Konsentrasi 0 ppm) & 21,27 & $\mathrm{~d}$ \\
G1 (Konsentrasi 125 ppm) & 24,04 & $\mathrm{c}$ \\
G2 (Konsentrasi 250 ppm) & 26,17 & $\mathrm{~b}$ \\
G3 (Konsentrasi 375 ppm) & 29,77 & $\mathrm{a}$ \\
\hline
\end{tabular}

Keterangan: Rata-rata yang diikuti huruf yang sama meununjukan berpengaruh tidak nyata pada uji jarak berganda Duncan taraf 5\%

Tabel 2 menyatakan bahwa pada pengamatan hasil analisis jarak berganda Duncan beberapa konsentrasi Giberellin GA3 terhadap jumlah buah per tanaman, menunjukkan perlakuan pemberian Giberellin 0 ppm (G0), 125 ppm (G1), 250 ppm (G2), dan 375 ppm (G3), saling berpengaruh nyata. Pemberian Giberellin GA3 375 ppm (G3) cenderung memberikan hasil jumlah buah per tanaman yang terbaik sebanyak 30 buah. Terlihat pada hasil penelitian memang pada perlakuan Giberellin GA3 sangatlah berpengaruh pada jumlah buah juga pada pertumbuhan tanaman. Hal ini terbukti sejalan dengan pendapat Salisbury dan Ross (1995), bahwa hormon giberelin dengan konsentrasi yang cocok, bukan hanya untuk pemanjangan batang saja namun juga pertumbuhan seluruh tumbuhan dapat terpacu dan berakibat pada mengarahkan pada produksi.

Effektivitas Produksi jumlah buah per tanaman : $=\frac{G 3-G 0}{G 3} \times 100 \%=\frac{29,77-21,27}{29,77} \times 100 \%=$ $28 \%$

Tabel 3. Jumlah buah per tanaman yang dipengaruhi faktor pemberian Pupuk Hayati pada berbagai konsentrasi

\begin{tabular}{lcc}
\hline \multicolumn{2}{c}{ Pemberian Pupuk Hayati } & Jumlah Buah Per Tanaman \\
\hline H0 (Konsentrasi $0 \mathrm{ml})$ & 23,42 & $\mathrm{c}$ \\
H1 (Konsentrasi $40 \mathrm{ml}$ ) & 26,52 & $\mathrm{a}$ \\
H2 (Konsentrasi $80 \mathrm{ml}$ ) & 25,62 & $\mathrm{~b}$ \\
H3 (Konsentrasi $120 \mathrm{ml}$ ) & 25,69 & $\mathrm{~b}$ \\
\hline gan : Rata-rata yang diikuti huruf yang sama meununjukan berpengaruh tidak nyata pada uji \\
$\quad$ jarak berganda Duncan taraf 5\%
\end{tabular}


Jumlah buah per tanaman pada Tabel 3 menunjukkan bahwa berdasarkan perlakuan faktor pemberian Pupuk Hayati pada konsentrasi 80 ml/l (H2) dan 120 ml/l (H3) sama-sama berpengaruh tidak nyata, sedangkan pada konsentrasi $0 \mathrm{ml} / \mathrm{l}(\mathrm{H} 0)$ dan $40 \mathrm{ml} / \mathrm{l}$ (H1) saling berpengaruh nyata. Perlakuan pemberian Pupuk Hayati dengan konsentrasi 40 ml/l (H1) cenderung menghasilkan jumlah buah per tanaman yang tertinggi yaitu sebanyak 26 buah. Hal ini menunjukkan bahwa hasil terbaik tidak hanya tertuju pada konsentrasi tinggi melainkan yang lebih efisien yaitu pada Pupuk Hayati pada konsentrasi $40 \mathrm{ml} / \mathrm{l}$ air (H1). Pernyataan ini senada dengan pendapat Setyamidjaja (1986), bahwa peningkatan produksi pertanian tidak lepas dari peranan pupuk sebagai bahan penyubur, yang belum tercapai dengan baik adalah salah meningkatkan efisiensi penggunaan pupuk.

Effektivitas Produksi jumlah buah per tanaman : $\frac{H 1-H 0}{H 1} \times 100 \%=\frac{26,52-23,42}{26,52} \times 100 \%=$ $12 \%$

Tabel 4. Jumlah buah per tanaman yang dipengaruhi oleh interaksi antara pemberian Giberellin GA3 (G) dan Pupuk Hayati $(\mathrm{H})$ pada berbagai konsentrasi

\begin{tabular}{ccc}
\hline Interaksi G X H & Jumlah Buah Per Tanaman \\
& & \\
\hline G3H1 & 33,08 & $\mathrm{a}$ \\
G3H3 & 29,08 & $\mathrm{~b}$ \\
G3H2 & 28,75 & $\mathrm{c}$ \\
G3H0 & 28,17 & $\mathrm{~d}$ \\
G2H2 & 27,67 & $\mathrm{e}$ \\
G2H1 & 26,08 & $\mathrm{f}$ \\
G2H3 & 25,83 & $\mathrm{~g}$ \\
G2H0 & 25,08 & $\mathrm{~h}$ \\
G1H1 & 24,33 & $\mathrm{i}$ \\
G1H3 & 24,25 & $\mathrm{j}$ \\
G1H0 & 24,17 & $\mathrm{k}$ \\
G0H3 & 23,58 & $\mathrm{1}$ \\
G1H2 & 23,42 & $\mathrm{~m}$ \\
G0H2 & 22,67 & $\mathrm{n}$ \\
G0H1 & 22,58 & $\mathrm{o}$ \\
G0H0 & 16,25 & $\mathrm{p}$ \\
\hline
\end{tabular}

Keterangan : Rata-rata yang diikuti huruf yang sama meununjukan berpengaruh tidak nyata pada uji jarak berganda Duncan taraf 5\%

Pada interaksi antara pemberian Giberellin GA3 (G) dan Pupuk Hayati (H) pada Tabel 4, diketahui bahwa masing-masing interaksi perlakuan menunjukkan hasil yang saling berpengaruh nyata. Hasil analisis terhadap jumlah buah per tanaman cenderung yang terbaik terdapat pada interaksi perlakuan Giberellin GA3 pada konsentrasi 375 ppm dan Pupuk Hayati pada konsentrasi $40 \mathrm{ml} / \mathrm{l}$ air (G3H1) sebesar 33 buah. 
Interaksi yang menunjukkan hasil sangat berpengaruh nyata pada pengamatan jumlah buah per tanaman dikarenakan bahwa pemberian Giberellin GA3 dan Pupuk Hayati saling mendukung. Menurut Salisbury dan Ross (1995), bahwa hormon giberelin GA3 dengan konsentrasi yang cocok, bukan hanya untuk pemanjangan batang saja namun pertumbuhan seluruh tumbuhan dapat terpacu dan akibatnya akan mengarah pada produksi. Selanjutnya Simanungkalit et al., (2006) menyatakan bahwa pemberian dosis pupuk hayati yang berlebihan akan menyebabkan terjadinya persaingan antar mikroba dalam memperoleh makanan sehingga akan berpengaruh terhadap kebutuhan nutrisimikroba, akibatnya mikroba akan bekerja kurang optimal sehingga pengaruhnya terhadap tinggi tanaman juga kurang optimal. Terbukti dengan pemberian Giberellin GA3 konsentrasi 375 ppm dan Pupuk Hayati konsentrasi $40 \mathrm{ml} / \mathrm{l}$ air (G3H1) sangatlah cocok dan mampu memberikan hasil terbaik.

Effektivitas jumlah buah per tanaman : : $\frac{G 3 H 1-G 0 H 0}{G 3 H 1} \times 100 \%=\frac{33,08-16,25}{33,08} \times 100 \%=51 \%$

\section{Jumlah Buah Per Petak}

Hasil analisis ragam terhadap jumlah buah per petak menunjukkan bahwa perlakuan pemberian konsentrasi Giberellin GA3, pemberian kon sentrasi Pupuk Hayati dan interaksi kedua faktor tersebut sama-sama menunjukkan berpengaruh sangat nyata dengan dilanjutkan analisis uji beda jarak berganda Duncan.

Tabel 5. Jumlah buah per petak yang dipengaruhi oleh faktor pemberian Giberellin GA3 pada berbagai konsentrasi

\begin{tabular}{lll}
\hline \multicolumn{1}{c}{ Pemberian Giberellin } & Jumlah Buah Per petak & \\
& & \\
\hline \hline G0 (Konsentrasi 0 ppm) & 531,42 & $\mathrm{~d}$ \\
G1 (Konsentrasi 125 ppm) & 596,84 & $\mathrm{c}$ \\
G2 (Konsentrasi 250 ppm) & 658,92 & $\mathrm{~b}$ \\
G3 (Konsentrasi 375 ppm) & 770,34 & $\mathrm{a}$ \\
\hline
\end{tabular}

Keterangan : Rata-rata yang diikuti huruf yang sama meununjukan berpengaruh tidak nyata pada uji jarak berganda Duncan taraf 5\%

Tabel 5 menunjukkan pada pengamatan hasil analisis jarak berganda Duncan beberapa konsentrasi Giberellin GA3 terhadap jumlah buah per petak, menyatakan bahwa perlakuan pemberian Giberellin GA3 0 ppm (G0), 125 ppm (G1), 250 ppm (G2) dan 375 ppm (G3), saling berpengaruh nyata. Pemberian Giberellin GA3 375 ppm (G3) cenderung memperoleh hasil jumlah per petak yang terbaik sebanyak 770 buah. Menurut (Saptowo dalam AgroBio, 2001) bahwa penambahan giberelin GA3 memacu tanaman membentuk buah yang dikarenakan dapat menaikan produksi hormon absisat. 
Effektivitas Produksi jumlah buah per petak : $\frac{G 3-G 0}{G 3} \times 100 \%=\frac{770,34-531,42}{770,34} \times 100 \%=31 \%$

Tabel 6. Jumlah buah per petak yang dipengaruhi oleh faktor pemberian Pupuk Hayati pada berbagai konsentrasi

\begin{tabular}{lcc}
\hline \multicolumn{1}{c}{ Pemberian Pupuk Hayati } & Jumlah Buah Per petak & \\
& & \\
\hline H0 (Konsentrasi 0 ml/l) & 602,67 & $\mathrm{~d}$ \\
H1 (Konsentrasi $40 \mathrm{ml} / \mathrm{l})$ & 669,75 & $\mathrm{a}$ \\
H2 (Konsentrasi $80 \mathrm{ml} / \mathrm{l})$ & 639,75 & $\mathrm{c}$ \\
H3 (Konsentrasi $120 \mathrm{ml} / \mathrm{l})$ & 645,33 & $\mathrm{~b}$ \\
\hline
\end{tabular}

Keterangan : Rata-rata yang diikuti huruf yang sama menunjukkan berpengaruh tidak nyata pada uji jarak berganda Duncan taraf 5\%

Jumlah buah per petak pada Tabel 6 menunjukkan bahwa pada pengamatan hasil analisis jarak berganda Duncan beberapa konsentrasi Pupuk Hayati, perlakuan pemberian Pupuk Hayati K-Bioboost dengan konsentrasi 0 ml/l air (H0), 40 ml/l air (H1), 80 ml/l air (H2), dan $120 \mathrm{ml} / \mathrm{l}$ air (H3), saling berpengaruh nyata. Pemberian Pupuk Hayati dengan konsentrasi $40 \mathrm{ml} / \mathrm{l}$ air (H1) cenderung memberikan hasil jumlah buah per petak yang terbaik yitu seberat 700 gram. Pemupukan tanaman akan lebih baik bila menggunakan jenis pupuk, dosis, cara, dan waktu pemberian yang tepat dan ternyata pemberian dengan konsentrasi 40 $\mathrm{ml} / \mathrm{l}$ air (H1) lah yang paling produktif. Hal tersebut sejalan dengan pendapat Zahra (2011) bahwa jika kekurangan atau kelebihan unsur hara termasuk $\mathrm{N}, \mathrm{P}$, dan $\mathrm{K}$ akan berpengaruh tidak baik terhadap pertumbuhan dan produksi tanaman.

Effektivitas Produksi jumlah buah per petak : $\frac{H 1-H 0}{H 1} \times 100 \%=\frac{669,75-602,67}{669,75} \times 100 \%=10 \%$

Tabel 7. Jumlah buah per petak yang dipengaruhi oleh interaksi antara pemberian kon konsentrasi Giberellin GA3 (G) dan pemberian konsentrasi Pupuk Hayati (H) pada berbagai konsentrasi

\begin{tabular}{ccc}
\hline Interaksi G X H & Jumlah Buah Per petak \\
\hline \hline G3H1 & 835,67 & $\mathrm{a}$ \\
G3H3 & 754,00 & $\mathrm{~b}$ \\
G3H2 & 747,00 & $\mathrm{c}$ \\
G3H0 & 744,67 & $\mathrm{~d}$ \\
G2H2 & 672,67 & $\mathrm{e}$
\end{tabular}




\begin{tabular}{lcc} 
G2H3 & 672,67 & $\mathrm{e}$ \\
G2H1 & 654,67 & $\mathrm{f}$ \\
G2H0 & 635,67 & $\mathrm{~g}$ \\
G1H1 & 621,00 & $\mathrm{~h}$ \\
G1H3 & 596,00 & $\mathrm{i}$ \\
G1H0 & 593,33 & $\mathrm{j}$ \\
G1H2 & 577,00 & $\mathrm{k}$ \\
G0H1 & 567,67 & 1 \\
G0H2 & 562,33 & $\mathrm{~m}$ \\
G0H3 & 558,67 & $\mathrm{n}$ \\
G0H0 & 437,00 & $\mathrm{o}$ \\
\hline
\end{tabular}

Keterangan : Rata-rata yang diikuti huruf yang sama meununjukan berpengaruh tidak nyata pada uji jarak berganda Duncan taraf $5 \%$

Pada interaksi perlakuan konsentrasi giberelin GA3 dan konsentrasi pupuk hayati pada Tabel 7 diketahui bahwa pemberian Giberellin GA3 pada konsentrasi 250 ppm dan pemberian Pupuk Hayati K-Bioboost pada konsentrasi $80 \mathrm{ml} / \mathrm{l}(\mathrm{G} 2 \mathrm{H} 2)$ berpengaruh tidak nyata dengan perlakuan Giberellin GA3 pada konsentrasi 250 ppm dan Pupuk Hayati pada konsentrasi $120 \mathrm{ml} / \mathrm{l}$ air (G2H3). Sedangkan interaksi perlakuan lainnya saling berpengaruh nyata. Hasil analisis terhadap jumlah buah per petak cenderung yang terbaik terdapat pada interaksi perlakuan Giberellin GA3 pada konsentrasi 375 ppm dan perlakuan Pupuk Hayati pada konsentrasi $40 \mathrm{ml} / \mathrm{l}$ air (G3H1) sebanyak 836 buah.

Interaksi yang menunjukkan hasil sangat berpengaruh nyata pada pengamatan jumlah buah per petak dikarenakan pemberian Giberellin GA3 dan Pupuk Hayati K-Bioboost saling mendukung. Menurut Schaffer dan Andersen (1994), dalam Mollier (2010) bahwa hasil panen melibatkan interaksi beberapa tipe tanaman dan faktor eksternal. Hal ini sangat tergantung pada produksi dan mobilisasi karbohidrat, penyerapan nutrisi dan air dari tanah dan keseimbangan hormonal dan beberapa faktor lingkungan selama masa pertumbuhan mempunyai peranan dalam mendukung perpanjangan sel, pembelahan sel, dan pembentukan RNA dan protein, akibatnya proses fisiologis tersebut akan mendorong meningkatkan kegiatan organ-organ bagian tanaman (Sure et al.2013). Pemberian pupuk organik hayati dapat meningkatkan ketersediaan dan serapan unsur hara $\mathrm{P}$ oleh tanaman okra yang selanjutnya dapat mempercepat proses pembungaan dan masaknya buah. Seperti dikemukakan oleh Lingga dan Marsono (2002) bahwa unsur hara P sangat diperlukan dalam proses asimilasi, respirasi, dan berperan dalam mempercepat proses pembungaan dan pemasakan buah.

Effektivitas Produksi Jumlah Buah Per Petak:

$$
=\frac{G 3 H 1-G 0 H 0}{G 3 H 1} \times 100 \%=\frac{835,67-437,00}{835,67} \times 100 \%=48 \%
$$

Menurut pengamatan jumlah buah per petak pada pemberian interaksi antara Giberellin GA3 pada konsentrasi 375 ppm dan pemberian Pupuk Hayati pada konsentrasi 40 
$\mathrm{ml} / \mathrm{l}$ (G3H1) yang dijabarkan rumus di atas lebih efektif yang dapat ditunjukkan oleh meningkatnya produksi sebesar $48 \%$.

\section{Berat Buah Per Tanaman}

Hasil analisis ragam terhadap berat buah menunjukkan bahwa perlakuan pemberian Giberellin GA3, pemberian Pupuk Hayati, dan interaksi dari kedua faktor tersebut sama-sama menunjukkan berpengaruh sangat nyata dengan dilanjutkan analisis uji beda jarak berganda Duncan

Tabel 8. Berat buah per tanaman yang dipengaruhi oleh faktor pemberian Giberellin GA3 pada berbagai konsentrasi

\begin{tabular}{lcc}
\hline Pemberian Giberelin GA3 & \multicolumn{2}{c}{ Berat Buah pertanaman (gram) } \\
\hline G0 (Konsentrasi 0 ppm) & 4,71 & $\mathrm{~d}$ \\
G1 (Konsentrasi 125 ppm) & 4,81 & $\mathrm{c}$ \\
G2 (Konsentrasi 250 ppm) & 4,90 & $\mathrm{~b}$ \\
G3 (Konsentrasi 375 ppm) & 5,15 & $\mathrm{a}$ \\
\hline
\end{tabular}

Keterangan : Rata-rata yang diikuti huruf yang sama meununjukan berpengaruh tidak nyata pada uji jarak berganda Duncan taraf 5\%

Berat buah per tanaman pada Tabel 8 menunjukkan bahwa pada pengamatan hasil analisis jarak berganda Duncan beberapa konsentrasi Giberellin GA3, perlakuan pemberian Giberellin GA3 pada konsentrasi 0 ppm (G0), 125 ppm (G1), 250 ppm (G2) dan 375 ppm (G3), saling berpengaruh nyata. Pemberian Giberellin GA3 pada konsentrasi 375 ppm (G3) cenderung memberikan hasil buah okra per tanaman yang terbaik yaitu seberat 5 gram. Hal tersebut menunjukkan bahwa perlakuan pemberian hormon giberelin GA3 berpengaruh nyata terhadap bobot buah okra. Menurut Annisah (2009), bahwa hormon giberelin GA3 berpengaruh terhadap pembentangan sel-sel, pembungaan, dan pembuahan. Giberelin GA3 juga mampu menginduksi terjadinya pembelahan pada sel-sel buah sehingga efektifitas ukuran buah bertambah.

Effektivitas Produksi berat buah: : $\frac{G 3-G 0}{G 3} \times 100 \%=\frac{5,15-4,71}{5,15} \times 100 \%=8 \%$

Tabel 9. Berat buah per tanaman yang dipengaruhi faktor pemberian Pupuk Hayati pada berbagai konsentrasi

\section{Pemberian Pupuk Hayati $\quad$ Berat Buah Per Tanaman (gram)}

\begin{tabular}{lll}
\hline H0 (Konsentrasi $0 \mathrm{ml})$ & 4,72 & $\mathrm{c}$ \\
H1 (Konsentrasi $40 \mathrm{ml})$ & 4,98 & $\mathrm{a}$ \\
H2 (Konsentrasi $80 \mathrm{ml})$ & 4,92 & $\mathrm{~b}$ \\
H3 (Konsentrasi $120 \mathrm{ml})$ & 4,94 & $\mathrm{~b}$ \\
\hline
\end{tabular}


Keterangan : Rata-rata yang diikuti huruf yang sama meununjukan berpengaruh tidak nyata pada uji jarak berganda Duncan taraf 5\%

Berat buah per tanaman pada Tabel 9 menunjukkan bahwa pada pengamatan hasil analisis jarak berganda Duncan beberapa konsentrasi Pupuk Hayati, perlakuan pemberian Pupuk Hayati dengan konsentrasi $0 \mathrm{ml} / \mathrm{l}$ (H0), $40 \mathrm{ml} / \mathrm{l}$ (H1) saling berpengaruh nyata. Sedangkan $80 \mathrm{ml} / \mathrm{l}$ air (H2) dan $120 \mathrm{ml} / \mathrm{l}$ air (H3), saling berpengaruh tidak nyata. Pemberian Pupuk Hayati dengan konsentrasi $40 \mathrm{ml} / \mathrm{l}$ air (H1) cenderung memberikan hasil berat buah per tanaman yang terbaik seberat 5 gram. Dauda dkk. (2008) menyarankan bahwa untuk meningkatkan produksi semangka dan menjaga kualitas tanah perlu adanya pemanfaatan pupuk organik. Dapat dilihat dari Tabel 18 cukup dengan konsentrasi 40 ml/l (H1) saja sudah menunjukkan pengaruh yang nyata pada berat buah per tanaman okra.

Effektivitas Produksi berat buah: : $\frac{H 1-H 0}{H 1} \times 100 \%=\frac{4,98-4,72}{4,98} \times 100 \%=5 \%$

Tabel 10. Berat buah per tanaman pada interaksi antara Giberellin GA3 (G) dan Pupuk Hayati (H) pada berbagai konsentrasi

\begin{tabular}{ccc}
\hline Interaksi G X H & \multicolumn{2}{c}{ Berat Buah (gram) } \\
\hline \hline G3H1 & 5,21 & $\mathrm{a}$ \\
G3H2 & 5,17 & $\mathrm{~b}$ \\
G3H0 & 5,14 & $\mathrm{c}$ \\
G3H3 & 5,07 & $\mathrm{~d}$ \\
G2H1 & 5,00 & $\mathrm{e}$ \\
G2H2 & 4,98 & $\mathrm{f}$ \\
G2H3 & 4,90 & $\mathrm{~g}$ \\
G1H3 & 4,90 & $\mathrm{~g}$ \\
G1H1 & 4,89 & $\mathrm{~g}$ \\
G0H3 & 4,88 & $\mathrm{~h}$ \\
G0H2 & 4,84 & $\mathrm{i}$ \\
G0H1 & 4,83 & $\mathrm{j}$ \\
G1H0 & 4,75 & $\mathrm{k}$ \\
G2H0 & 4,70 & $\mathrm{l}$ \\
G1H2 & 4,69 & $\mathrm{l}$ \\
G0H0 & 4,31 & $\mathrm{~m}$
\end{tabular}

Keterangan : Rata-rata yang diikuti huruf yang sama meununjukan berpengaruh tidak nyata pada uji jarak berganda Duncan taraf 5\%

Pada interaksi Giberellin GA3 pada konsentrasi 250 ppm dan Pupuk Hayati KBioboost pada Tabel 10, diketahui bahwa pada pada konsentrasi $120 \mathrm{ml} / 1$ air (G2H3) berpengaruh tidak nyata dengan interaksi Giberellin GA3 pada konsentrasi 125 ppm dan 
Pupuk Hayati pada konsentrasi 120ml/1 air (G1H3) dan Giberellin GA3 konsentrasi 125 ppm dan Pupuk Hayati konsentrasi 40 ml/l air (G1H1). Kemudian pada interaksi Giberellin GA3 konsentrasi $250 \mathrm{ppm}$ dan Pupuk Hayati konsentrasi $0 \mathrm{ml} / \mathrm{l}$ (G2H0) berpengaruh tidak nyata dengan interaksi Giberellin GA3 konsentrasi 0 ppm dan Pupuk Hayati konsentrasi $0 \mathrm{ml} / \mathrm{l}$ air (G0H0). Hasil analisis terhadap berat buah okra cenderung yang terbaik terdapat pada interaksi perlakuan Giberellin GA3 konsentrasi 375 ppm dan perlakuan Pupuk Hayati konsentrasi $40 \mathrm{ml} / \mathrm{l}$ air (G3H1) seberat 5 gram. Interaksi yang menunjukkan hasil sangat berpengaruh nyata pada pengamatan berat buah per tanaman dikarenakan pemberian Giberellin GA3 dan Pupuk Hayati saling mendukung. Pemberian konsentrasi giberelin GA3 yang optimal akan membantu dalam pembesaran buah karena setelah fertilisasi, sintesis giberelin terjadi pada endosperm dan embrio, sehingga giberelin GA3 diperlukan untuk pertumbuhan buah (Wilkins, 1992). Menurut Sumpena (2006), bahwa meningkatnya fotosintat berpengaruh terhadap pengisian buah yang secara tidak langsung menentukan berat buah. Unsur P juga dapat mempercepat proses pematangan dan membantu pengangkutan karbohidrat dari bagian lain, seperti cabang dan daun ke buah sehingga buah yang terbentuk menjadi lebih berisi dan memiliki bobot yang optimum. Hal tersebut didukung pendapat Syarief (1986) yang menyatakan bahwa tersedianya unsur hara yang cukup pada saat pertumbuhan menyebabkan metabolisme tanaman lebih aktif sehingga proses pemanjangan, pembelahan, dan diferensiasi sel akan lebih baik yang akhirnya dapat mendorong peningkatan bobot buah.

Efektifitas Produksi berat buah: : $\frac{G 3 H 1-G 0 H 0}{G 3 H 1} \times 100 \%=\frac{5,21-4,31}{5,21} \times 100 \%=17 \%$

\section{Berat Buah Per Petak}

Hasil analisis ragam terhadap berat buah per petak menunjukkan bahwa perlakuan pemberian Giberellin GA3, pemberian Pupuk Hayati, dan interaksi kedua faktor tersebut sama-sama menunjukkan berpengaruh sangat nyata dengan dilanjutkan analisis uji beda jarak berganda Duncan.

Tabel 11. Berat buah per petak yang dipengaruhi oleh faktor pemberian Giberellin GA3 pada berbagai konsentrasi

\begin{tabular}{cc}
\hline Pemberian Giberellin & Berat Buah Per Petak (gram) \\
\hline \hline G0 (Konsentrasi 0 ppm) & $2162,00 \mathrm{~d}$ \\
G1 (Konsentrasi 125 ppm) & $2445,42 \mathrm{c}$ \\
G2 (Konsentrasi 250 ppm) & $2649,17 \mathrm{~b}$ \\
G3 (Konsentrasi 375 ppm) & $3108,67 \mathrm{a}$ \\
\hline
\end{tabular}

Keterangan : Rata-rata yang diikuti huruf yang sama meununjukan berpengaruh tidak nyata pada uji jarak berganda Duncan taraf 5\%

Berat buah per petak pada Tabel 11, menunjukkan bahwa pada pengamatan hasil analisis jarak berganda Duncan beberapa konsentrasi Giberellin, perlakuan pemberian 
Giberellin GA3 0 ppm (G0), 125 ppm (G1), 250 ppm (G2), dan 375 ppm (G3) saling berpengaruh nyata. Pemberian Giberellin 375 ppm (G3) cenderung memberikan hasil berat buah per petak yang terbaik yaitu seberat 3109 gram. Tabel 20 memberikan gambaran bahwa fase penambahan berat buah berkaitan dengan peningkatan konsentrasi di dalam buah, penambahan padatanaman akan meningkatkan ukuran sel sehingga terjadi penambahan bera bua oleh hasil fotosintat. Hal tersebut didukung pula oleh kandungan hormon lainnya yang berada dalam buah. Hal ini sejalan dengan pernyataan Saptowo dalam AgroBio (2001), bahwa peningkatan produksi fotosintesis yang pesat akan menambah $\mathrm{C} / \mathrm{N}$ rasio menjadi relatif lebih besar. Kondisi ini mendorong tanaman beralih fase dari fase vegetatif ke fase genetatif. Fase genetatif tanaman memacu pembentukan jaringan penyimpanan. Sel-sel jaringan penyimpanan akan terbentuk lebih banyak dan lebih besar.

Effektivitas Produksi berat buah per petak: $\frac{G 3-G 0}{G 3} \times 100 \%=\frac{3108,67-2162,00}{3108,67} \times 100 \%=30 \%$

Tabel 12. Berat buah per petak yang dipengaruhi oleh faktor pemberian Pupuk Hayati pada berbagai konsentrasi

\begin{tabular}{lcc}
\multicolumn{1}{c}{ Pemberian Pupuk Hayati } & Berat Buah Per Ppetak (gram) \\
\hline H0 (Konsentrasi $0 \mathrm{ml} / \mathrm{l})$ & 2460,17 & $\mathrm{~d}$ \\
H1 (Konsentrasi $40 \mathrm{ml} / \mathrm{l})$ & 2688 & $\mathrm{a}$ \\
H2 (Konsentrasi $80 \mathrm{ml} / \mathrm{l})$ & 2595,5 & $\mathrm{c}$ \\
H3 (Konsentrasi $120 \mathrm{ml} / \mathrm{l})$ & 2621,58 & $\mathrm{~b}$ \\
\hline
\end{tabular}

Keterangan : Rata-rata yang diikuti huruf yang sama meununjukan berpengaruh tidak nyata pada uji jarak berganda Duncan taraf 5\%

Berat buah per petak pada Tabel 12 menunjukkan bahwa pada pengamatan hasil analisis jarak berganda Duncan beberapa konsentrasi Pupuk Hayati, perlakuan pemberian Pupuk Hayati dengan konsentrasi 0 ml/l air (H0), 40 ml/l air (H1), 80 ml/l air (H2), dan 120 $\mathrm{ml} / \mathrm{l}$ air (H3), saling berpengaruh nyata. Pemberian Pupuk Hayati boost dengan konsentrasi $40 \mathrm{ml} / \mathrm{l}(\mathrm{H} 1)$ cenderung memberikan hasil berat buah per petak yang terbaik, yaitu seberat 2688 gram. Menurut Subhan et al. (2005) mengungkap bahwa pemberian pupuk organik dapat meningkatkan hasil buah tomat di tanah Andosol Garut.

Effektivitas Produksi berat buah per petak: $\frac{H 1-H 0}{H 1} \times 100 \%=\frac{2688,00-2460,17}{2688,00} \times 100 \%=8 \%$

Tabel 13. Berat buah per petak yang dipengaruhi oleh interaksi pemberian Giberellin GA3 (G) dan pemberian Pupuk Hayati $(\mathrm{H})$ pada berbagai konsentrasi.

Interaksi G X H Berat Buah Per Petak (gram)

G3H1 $7343,00 \quad$ a




\begin{tabular}{lll} 
G3H3 & 7067,00 & $\mathrm{~b}$ \\
G3H0 & 7025,67 & $\mathrm{c}$ \\
G3H2 & 6999,00 & $\mathrm{~d}$ \\
$\mathrm{G} 2 \mathrm{H} 2$ & 6754,33 & $\mathrm{e}$ \\
$\mathrm{G} 2 \mathrm{H} 3$ & 6663,33 & $\mathrm{f}$ \\
$\mathrm{G} 2 \mathrm{H} 1$ & 6638,00 & $\mathrm{~g}$ \\
$\mathrm{G} 1 \mathrm{H} 1$ & 6548,33 & $\mathrm{~h}$ \\
$\mathrm{G} 2 \mathrm{H} 0$ & 6541,00 & $\mathrm{i}$ \\
$\mathrm{G} 1 \mathrm{H} 3$ & 6453,00 & $\mathrm{j}$ \\
$\mathrm{G} 1 \mathrm{H} 0$ & 6451,33 & $\mathrm{j}$ \\
$\mathrm{G} 1 \mathrm{H} 2$ & 6329,00 & $\mathrm{k}$ \\
$\mathrm{G} 0 \mathrm{H} 3$ & 6303,00 & $\mathrm{l}$ \\
G0H2 & 6299,67 & $\mathrm{l}$ \\
G0H1 & 6222,67 & $\mathrm{~m}$ \\
G0H0 & 5822,67 & $\mathrm{n}$ \\
\hline
\end{tabular}

Keterangan : Rata-rata yang diikuti huruf yang sama meununjukan berpengaruh tidak nyata pada uji jarak berganda Duncan taraf 5\%

Pada interaksi pemberian Giberellin GA3 pada konsentrasi 125 ppm dan Pupuk Hayati K-Bioboost pada Tabel 13, diketahui bahwa pada pada konsentrasi 120 ml/l (G1H3) berpengaruh tidak nyata dengan interaksi Giberellin GA3 konsentrasi 125 ppm dan Pupuk Hayati kosentrasi $0 \mathrm{ml} / \mathrm{l}$ (G1H0). Kemudian pada interaksi Giberellin GA3 konsentrasi 0 ppm dan Pupuk Hayati 120 ml/l (G0H3) berpengaruh tidak nyata dengan interaksi Giberellin GA3 konsentrasi 0 ppm dan Pupuk Hayati 80 ml/l (G0H2). Hasil analisis yang cenderung terbaik terdapat pada interaksi perlakuan Giberellin GA3 konsentrasi 375 ppm dan perlakuan Pupuk Hayati konsentrasi 40 ml/l air (G3H1) dengan rata-rata berat buah per petak 3343 gram. Peningkatan bobot segar pada konsentrasi yang optimum dibandingkan kontrol berbanding lurus dengan pernyataan dari Gelmesa (2010) bahwa pemberian konsentrasi dapat meningkatkan bobot buah rata-rata $27 \%$ dibandingkan tanpa perlakuan giberelin GA3 dan pupuk hayati. Selanjutnya menurut Mas'ud (1993) dalam Neliyati (2012) menyatakan bahwa translokasi fotosintat ke buah tanaman tomat nyata dipengaruhi oleh kalium, peranan kalium mempertinggi pergerakan fotosintat keluar dari daun menuju akar, dan hal tersebut akan meningkatkan penyediaan energi untuk pertumbuhan akar, perkembangan ukuran serta kualitas buah sehingga bobot buah bertambah.

Effektivitas Produksi berat buah per petak :

$$
=\frac{G 3 H 1-G 0 H 0}{G 3 H 1} \times 100 \%=\frac{3343,00-1822,66}{3343,00} \times 100 \%=45 \%
$$

Jika dikonversikan dalam satuan ton/ha maka menggunakan rumus sebagai berikut .

Konversi ha : $\frac{\text { Luas lahan } 1 \mathrm{Ha}}{\text { Luas petak }} \times G 3 H 1=\frac{10.000}{3,3} \times 7343=22,25$ ton $/ \mathrm{ha}$ 


\section{Panjang Buah}

Hasil analisis ragam terhadap panjang buah menunjukkan bahwa perlakuan pemberian Giberellin GA3 dan pemberian Pupuk Hayati sama-sama berpengaruh sangat nyata dengan dilanjutkan analisis uji beda jarak berganda Duncan. Sedangkan interaksi kedua faktor menunjukkan tidak berpengaruh nyata.

Tabel 14. Panjang buah okra yang dipengaruhi oleh faktor pemberian Giberellin GA3 pada berbagai konsentrasi

\begin{tabular}{cc}
\hline Pemberian Giberellin & Panjang Buah $(\mathrm{cm})$ \\
\hline \hline G0 (Konsentrasi 0 ppm) & $6,41 \mathrm{~d}$ \\
G1 (Konsentrasi 125 ppm) & $6,49 \mathrm{c}$ \\
G2 (Konsentrasi 250 ppm) & $6,53 \mathrm{~b}$ \\
G3 (Konsentrasi 375 ppm) & $6,55 \mathrm{a}$ \\
\hline
\end{tabular}

Keterangan : Rata-rata yang diikuti huruf yang sama meununjukan berpengaruh tidak nyata pada uji jarak berganda Duncan taraf 5\%

Panjang buah okra pada Tabel 14, menunjukkan bahwa pada pengamatan hasil analisis jarak berganda Duncan beberapa konsentrasi Giberellin GA3 perlakuan pemberian Giberellin GA3 0 ppm (G0), 125 ppm (G1), 250 ppm (G2) dan 375 ppm (G3), saling berpengaruh nyata. Pemberian Giberellin GA3 pada konsentrasi 375 ppm (G3) cenderung memberikan hasil terbaik dengan rata-rata $6,55 \mathrm{~cm}$ buah per tanaman. Salisbury dan Ross (1995), hormon giberelin dengan konsentrasi yang cocok, bukan hanya untuk pemanjangan batang saja namun pertumbuhan seluruh tumbuhan dapat terpacu dan nantinya akan mengarah pada produksi. Terbukti pada pengamatan tinggi tanaman, jumlah buah, dan jumlah bunga tanaman okra pada pemberian Giberellin GA3 konsentrasi 375 ppm (G3) menunjukkan hasil paling baik. Hal tersebut sejalan dengan Annisah (2009), hormon giberelin GA3 berpengaruh terhadap pembentangan sel-sel, pembungaan, dan pembuahan. Giberelin GA3 juga mampu menginduksi terjadinya pembelahan pada sel-sel buah sehingga ukuran buah bertambah.

Tabel 15. Panjang buah yang dipengaruhi faktor pemberian Pupuk Hayati K-Bioboost pada berbagai konsentrasi

\begin{tabular}{lcc}
\hline Pemberian Pupuk Hayati & Panjang Buah $(\mathrm{cm})$ & \\
& & $\mathrm{c}$ \\
\hline \hline H0 (Konsentrasi 0 ml/l) & 6,4 & $\mathrm{a}$ \\
H1 (Konsentrasi $40 \mathrm{ml} / \mathrm{l})$ & 6,55 & $\mathrm{~b}$ \\
H2 (Konsentrasi $80 \mathrm{ml} / \mathrm{l})$ & 6,51 & $\mathrm{~b}$ \\
H3 (Konsentrasi $120 \mathrm{ml} / \mathrm{l})$ & 6,507 &
\end{tabular}

Keterangan : Rata-rata yang diikuti huruf yang sama meununjukan berpengaruh tidak nyata pada uji jarak berganda Duncan taraf 5\% 
Tabel 15, menunjukkan pada pengamatan hasil analisis jarak berganda Duncan beberapa konsentrasi Pupuk Hayati terhadap panjang buah, bahwa perlakuan pemberian Pupuk Hayati K-Bioboost dengan konsentrasi 0 ml/l air (H0) dan sedangkan 40 ml/l air (H1) saling berpengaruh nyata, sedangkan $80 \mathrm{ml} / \mathrm{l}$ air (H2) dan $120 \mathrm{ml} / \mathrm{l}$ air (H3), saling berpengaruh tidak nyata. Pemberian Pupuk Hayati dengan konsentrasi $40 \mathrm{ml} / \mathrm{l}$ air (H1) cenderung memberikan hasil terbaik dengan rata-rata $6,55 \mathrm{~cm}$ buah per tanaman. Unsur hara yang tersedia untuk pertumbuhan tanaman akan menyebabkan kegiatan penyerapan hara dan fotosintesis berjalan dengan baik sehingga fotosintat yang terakumulasi juga ikut meningkat dan akan berdampak terhadap bobot dan panjang buah. Sudjijo (1996) menyatakan bahwa besarnya jumlah hara yang diserap oleh tanaman sangat bergantung dari pupuk yang diberikan, dimana hara yang diserap oleh tanaman akan dimanfaatkan untuk proses fotosintesis yang pada akhirnya akan berpengaruh terhadap pertumbuhan maupun hasil yang diperoleh.

\section{KESIMPULAN}

1) Efektifitas Gibrelin GA3 terhadap produksi okra dengan konsentrasi terbaik pada konsentrasi $375 \mathrm{ppm}$ dapat meningkatkan produksi okra :

a) Pada variabel pengamatan jumlah buah per tanaman menunjukkan produksi sejumlah 30 buah dengan peningkatan efektivitas sebesar $28 \%$ dan pada variabel pengamatan jumlah buah per petak menunjukkan produksi sebanyak 770 buah dengan peningktan efektivitas sebesar $31 \%$.

b) Pada variabel pengamatan berat buah menunjukkan peningkatan produksi seberat 5,15 gram dengan peningktanan efektivitas sebesar 8\% dan pada variabel pengamatan berat buah per petak menunjukkan produksi seberat 3108,67 gram dengan peningkatan efektivitas sebesar $30 \%$.

2) Efektifitas Pupuk Hayati terhadap produksi okra dengan konsentrasi terbaik pada 40 $\mathrm{ml} / \mathrm{l} / \mathrm{l}$ air dapat meningkatkan produksi okra :

a) Pada variabel pengamatan jumlah buah per tanaman menunjukkan produksi sejumlah 27 buah dengan peningkatan efektivitas sebesar 12\% dan pada variabel pengamatan jumlah buah per petak menunjukkan produksi sejumlah 670 buah dengan peningkatan efektivitas sebesar $10 \%$.

b) Pada variabel pengamatan berat buah per tanaman menunjukkan produksi seberat 5,15 gram dengan peningktan efektivitas sebesar 5\% dan pada variabel pengamatan berat buah per petak menunjukkan produksi seberat 2688,00 gram dengan peningktan efektivitas sebesar $8 \%$.

3) Efektifitas interaksi antara Giberellin GA3 pada konsentrasi 375 ppm dan Pupuk Hayati pada konsentrasi $40 \mathrm{ml} / \mathrm{l} / \mathrm{l}$ air terhadap produksi okra :

a) Pada variabel pengamatan jumlah buah per tanaman menunjukkan produksi sebanyak 33 buah dengan peningkatan efektivitas sebesar 51\% dan pada variabel pengamatan 
jumlah buah per petak menunjukkan produksi sebanyak 836 buah dengan peningkatan efektivitas sebesar $48 \%$.

b) Variabel pengamatan berat buah per tanaman menunjukkan produksi seberat 5,21 gram dengan peningkatan efektivitas sebesar $17 \%$ dan pada variabel pengamatan berat buah per petak menunjukkan produksi seberat 7343 gram dengan peningkatan efektivitas sebesar 45\%, dengan konversi per hektar berat buah menjadi 22,25 ton.

\section{DAFTAR PUSTAKA}

Amritkar, A.S., H.S. Chaudhari, D.A. Narkhede, D.K. Jain, dan D.T. Baviskar. 2011. Nano technology forbio medical application. Int. J. Pharm.Sci.Rev.Res, 8(2): 45-53.

Annisah. 2009. Pengaruh Induksi Giberelin Terhadap Pembentukan Buah Partenokarpi Pada Beberapa Varietas Tanaman Semangka (Citrullus vulgaris Schard). (Skripsi) Program Studi Pemuliaan Tanaman, Fakultas Pertanian, Universitas Sumatra Utara.

Ansari, A.A. and S.A. Ismail. 2001. A Case Study on Organic Farmingin UttarPradesh. $J$. SoilBiol.Ecol., 27:25-27.

Ansari, A.A. and K. Sukhraj. 2010. Effect of vermiwash and vermicomposton soilparametersandproductivityofokra (Abelmoschus esculentus). In Guyana, African Journal of AgriculturalResearch., 5(14):1794-1798.

Ashari, S. 2006. Hortikultura Aspek Budidaya. UI Press, Jakarta.

Baktir, I, S. Ulger, L. Kaynak, D.G. Hilmerick. 2004. Relationship of seasonal changes in endogenous plant hormones and alternate bearing of olive trees. Hort Science 39(5): 987-990.

Brenner, M.L.L, and N. Cheikh. 1995. The role of hormones in photosynthate partitioning and seed filling. In : Plant Hormones, Physiology, Biochemistry and Molecular Biology. Dordrecht: Springer Netherlands, 649-70.

Campbell, N.A., J.B. Reece, and L. G. Mitchell. 2005. Biologi. Edisi ke-5.Terj. Dari: Biology. 5th ed. oleh Manulu, W. Jakarta: Erlangga.

Dauda SN, F.A. Ajayi, E. Ndor. 2008. Growth and yield of watermelon (Citrullus lunatus) as affected by poultry manure application. Journal of agriculture and social science 4: $121-124$.

Dewi, M. 2009. Respon Tanaman Okra (Abelmoschus esculentus L Moench) Terhadap Beberapa Jenis Tanah dan Pupuk Amazing Bio-Growth. Tesis Magister Pertanian pada Universitas IslamRiau : tidak diterbitkan.

El-Habbasha, S.F., M. Hozayn, and M.A. Khalafallah. 2007. Integration effect between phosphorus levels and bio-fertilizers on quality and quantity yield of faba bean (Vicia faba L.) in newly cultivated sandy soils. Res. J. Agric. And Bio. Sci., 3 (6), $966-$ 971.

Harjadi, S. S. 1993. Pengantar Agronomi. PT. Gramedia Pustaka Umum, Jakarta. 
Hartatik, W., D. Setyorini, dan S. Widati. 2006. Laporan Penelitian Teknologi Pengelolahan Hara Pada Budidaya Pertanian Organik. Balai Peneliti Tanah, Bogor.

Hopkins, W. G. 1995. Introduction to Plant Physiology. NewYork, Toronto, Singapore: John Wiley \& Sons, Inc. pp. 285-321.

Idawati. 2012. Peluang Besar Budidaya Okra. Yogyakarta, Pustaka Baru Press.

Jedeng, I.W. 2011. Uji Kerentanan Beberapa Serangga Hama Terhadap Infeksi Nematoda Heterorhabditis spp. (Rhabditida: Heterorhabditidae). Skripsi, Universitas Negeri Andalas, Padang.

Lakitan, B. 1996. Fisiologi Pertumbuhan dan Perkembangan Tanaman. PT Raja Grafindo Persada. Jakarta.

Lingga, P., dan Marsono. 2013. Petunjuk Penggunaan Pupuk. Edisi revisi, Cetakan Pertama, Penebar Swadaya, Jakarta.

Lengsfeld, H, dan H. Wolfer. 1988. Inhibition Of Pancreatic Lipase In Vitro By The Covalent Inhibitor Tetrahydroplastin. J. Biochem, 256:357-361.

Manuhutu, A.P., H. Rehatta dan J.J.G. Kailola. 2014. Pengaruh Konsentrasi Pupuk Hayati Bioboost terhadap Peningkatan Produksi Selada (Lactuca sativa). Jurnal AgrologiaVol 3 No 2. Ambon : Universitas Pattimura.

Mollier, M. 2010. Influence Of Plant Growth Regulators Ongrowth, Physiology, And Yield In Cucumber (Cucumis sativus L.). Department of Crop Physiology, College Of Agriculture, Dharwad, University of Agricultural Sciences, Dharwad, Thesis:1-72.

Naeem, A. Nomair, Batchelder, R. Michael, Hendren, dan Laurie. 2006. Metrics for Measuring the Effectiveness of Decompilers and Obfuscators. Sable Technical Report No. 2006-4, McGill University.

Neliyati. 2012. Pertumbuhan Hasil Tanaman Tomat pada Beberapa Dosis Kompos Sampah Kota. Jurnal Agronomi, 10(2): 93-97, Fakultas Pertanian, Universitas Jambi.

Nyanjang, R., A. A. Salim, dan Y. Rahmiati. 2003. Penggunaan Pupuk Majemuk NPK 25-77 Terhadap Peningkatan Produksi Mutu Pada Tanaman Teh Menghasilkan di Tanah Andisols. PT. Perkebunan Nusantara XII, Prosiding Teh Nasional, Gambung.

Putri, H.A. 2011. Pengaruh Pemberian Beberapa Konsentrasi Pupuk Organik Cair Lengkap (POCL) Bio Sugih Terhadap Pertumbuhan dan Hasil TanamanJagung Manis (Zea mays Saccharata Sturt.). [Skripsi] Fakultas Pertanian Universitas Andalas, Padang.

Purba, R. 2016. Respon pertumbuhan dan produksi kedelai terhadap pemupukan hayati pada lahan kering di Pandeglang, Banten. Jurnal Pengkajian dan Pengembangan Teknologi Pertanian, Vol. 19, No.3, 253-261.

Rachman, A.K. dan Y. Sudarto. 1991. Bertanam Okra. Yogyakarta, Kanisius.

Salisbury, F.B. dan C.W. Ross. 1995. Fisiologi Tumbuhan, Perkembangan Tumbuhan, dan Fisiologi Lingkungan. Institut Teknologi Bandung, Bandung.

Sanchez, P.A. 1992. Sifat Dan Pengelolaan Tanah Tropika. Terjemahan Properties and Management in The Tropics. ITB Press, Bandung. 
Santoso, U. dan N. Fatimah. 2004. Kultur Jaringan Tanaman. UMM-Press, Malang.

Saptowo, J.P., 2001. Pembentukan Buah Partenokarpi Melalui Rekayasa Genetik. Buletin Agbio Vol. 4 (2) Tahun 2001.

Sastry, K. K. S. and M.R. Muir. 1963. Gibberellin: Effect on Diffusible Auxin in Fruit Development. Science 140: 494-495.

Setyamidjaja, D. 1986. Pupuk dan Pemupukan. CV. Simplex. Jakarta.

Simanungkalit, R.D.M., A.S. Didi, S. Rasti., S. Diah, dan H. Wiwik. 2006. Pupuk Organik dan Pupuk Hayati Organic Fertilizer and Biofertilizer. Balai Besar Penelitian dan Pengembangan Sumberdaya Lahan Pertanian, Jawa Barat.

Sings, R.N. 2008. Controlled Atmospheres For Storageand Transportof Perishable Agricultural Comodities. Hort. Report, Nort Carolina State University.

Subhan, N., Nurtika and W. Setiawati. 2005. Peningkatan Efisiensi Pemupukan NPK dengan Memanfaatkan Bahan Organik Terhadap Hasil Tomat. J. Hort., vol.15, no. 2, hlm. 91-6.

Sudjijo. 1996. Dosis Pupuk Gandapan pada Tanaman Tomat Secara Hidroponik. Balai Penelitian Solok.

Sumpena, U. 2005. Budidaya Mentimun Intensif. Penebar Swadaya, Jakarta.

Suntoro, Syekhfani, E. Handayanto, dan Sumarno. 2014. Penggunaan Bahan Pangkasan 'Krinyu' (Chromolaena odorata) dan 'Gamal' (Gliricidias epium) Untuk Meningkatkan Ketersediaan P, K, Ca, dan Mg Pada Ozic Dystrundept. Agrivita, 23(1): 20-26.

Sure, S., H. Arooie and M. Azizi. 2013. Effect of and Ethephon on Sex Expression Andoilyieldin Medical Pumpkin (Cucurbit apeopvar Styriaca). International J. of Farming and Allied Sciences. 2(9):196-201.

Syafi'i, M. 2005. Pengaruh Konsentrasi dan Waktu Pemberian Giberelin (GA) Terhadap Pertumbuhan dan Hasil Tanaman Melon (Cucumis melo I.) dengan Sistem Tanam Hidroponik Irigasi Tetes. Availableat: http://core.ac.uk/. Diakses, 09 September.

Ton, S.W. 1991. Environmental Considerations With Use of Pesticides in Agriculture. Paper pada Lustrum ke-VIII Fakultas Pertanian USU, Medan.

Vriezen, W.H., R. Feron, F. Maretto, J. Keijman, and C. Mariani. 2008. Changes In Tomato Ovary Transcriptome Demonstrate Complex Hormonal Regulation Of Fruit Set. New Phytol., 177 : 60-76.

Yudo, K. 1991. Bertanaman Okra. Yogyakarta, Kasinius.

Zahrah, S. 2011. Respons Berbagai Varietas Kedelai (Glycine max L. Merril) terhadap Pemberian Pupuk NPK Organik. Tesis, Universitas Islam Riau. 